\title{
GIANT SOLITARY TRICHOEPITHELIOMA: A CASE REPORT
}

\author{
$K C G^{1}, K C S R^{3}$, Lakhey $A^{1}$, Singh $M^{2}$
}

${ }^{1}$ Department of Pathology, ${ }^{2}$ Department of Dermatology KIST Medical College, Imadol, Lalipur, Nepal, ${ }^{3}$ Department of

Pathology, Patan Academy of Health Sciences, Lalitpur, Nepal

\section{ABSTRACT}

Giant solitary trichoepithelioma (GST) is a rare adnexal skin tumor with hair structure differentiation. It varies from trichoepithelioma in size $(>2 \mathrm{~cm})$ and location (common in thigh and perianal region). So far only 18 cases of GST have been reported worldwide. This is a case of GST in the thigh of a 42 year old man. This form of trichoepithelioma can be a cellular tumor which needs to be differentiated from trichoblastoma, keratotic basal cell carcinoma, nevoid basal cell carcinoma and microcystic adnexal carcinoma.

\section{KEYWORDS}

Adnexal tumor, horn cyst, thigh lesion, trichoepithelioma

\section{CORRESPONDING AUTHOR}

Dr. Geetika KC

Lecturer,

Department of Pathology,

KIST Medical College, Imadol, Lalipur, Nepal

Email: geetikakc@hotmail.com 


\section{INTRODUCTION}

Among many tumors arising from the skin, skin adnexal tumor comprises a significant number of cases. Benign skin adnexal tumors are more prevalent than the malignant ones. Most of the adnexal tumors are predominantly dermal and many of them may show minimal epidermal connection. These are divided into basaloid, clear or eosinophilic and tumors with glandular differentiation. Trichoepithelioma is of the dermal adnexal tumor with hair structures differentiation. It can be small solitary, multiple or rarely giant solitary form. Though small solitary is quite common, giant solitary trichoepithelioma (GST) is a very rare form of trichoepithelioma with size ranging several centimeters. Common site of its occurrence are thigh and perianal region..$^{1,2}$ Here we present a case of GST in the thigh of a 42 year old man.

\section{CASE REPORT}

A 42 year old man presented with a slow growing nodular swelling, in his left thigh, since 2 years. The patient underwent excision biopsy. The biopsy specimen was sent to histopathology department of KIST medical college. On gross examination the mass was skin covered tissue that measured $5 \times 3.5 \times 2 \mathrm{~cm}$. Cut section revealed grayish white nodular surface. The specimen was processed and the sections were stained with Hematoxylin and Eosin (HE) stain. Multiple HE stained sections were examined. On the sections, the tissue was partially lined by keratinizing stratified squamous epithelium. The epidermis was insignificant (Fig. 1). Underlying dermis had nodule comprising of several basophilic islands of cells with lace-like and solid patterns. Peripheral palisading was noted in those islands (Fig. 2). The basophilic islands were surrounded by fibroblasts and no retraction clefts were noted. Occasional mitosis, horn cysts with abrupt keratinization (trichilemmal maturation) and several squamous eddies were seen. No cytological atypia, necrosis, brisk atypical mitosis or infiltration was noted (Fig. 2). Correlating the clinical and microscopic features, diagnosis of GST was made.

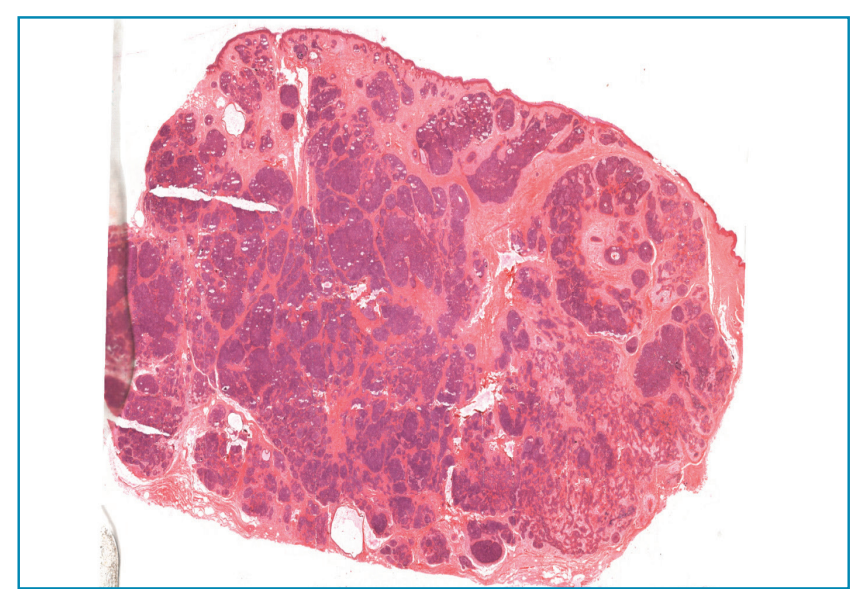

Fig. 1: Dermal lesion with several nests of tumor cells and few horn cysts (HE Stain, $4 \mathrm{X}$ )

\section{DISCUSSION}

Trichoepithelioma (TE) is a tumor located in the dermis. In literature, it was first described by Brooke in 1892 as "Epithelioma Adenoides Cysticum". ${ }^{3} \mathrm{He}$ hypothesized and demonstrated that it arises from the epidermis and epithelium of hair sacs. Later, Lever postulated that the origin of trichoepithelipma was germ cell or pluripotent embryonic stem cells or primary epithelial germ cells. ${ }^{4} \mathrm{TE}$ is benign cutaneous appendageal tumor and arises from hair follicles with some exocrine differentiation. ${ }^{5}$ There are three types of TE, a small solitary form, a small multiple form (autosomal dominant) and a giant solitary form. ${ }^{6}$

A small TE is the most common subtype and usually presents as a solitary nodule. It is seen in childhood or in young adulthood. The most common sites are face with a predilection for the nose, upper lip, and cheeks. Most of the small solitary lesions appear as a skin coloured papule and reaches up to $0.5 \mathrm{~cm}$ in dimension. ${ }^{4}$

Multiple TE can be seen in Brooke-Fordyce syndrome, transmitted as an autosomal dominant trait., ${ }^{7,8}$ They have less expressivity and penetrance in the male. In Brooke-Fordyce syndrome simultaneous presence of TE and cylindroma has been reported in several studies so far. ${ }^{9-11} \mathrm{TE}$ can also occur sporadically. Multiple TE present as small papules with a strong predilection for the central part of the face. Nevertheless, the trunk, neck and scalp may also be involved. The papules may coalesce to form plaques. Rarely, linear and dermatomal distribution may be seen. ${ }^{12}$

GST is a rare form of solitary TE measuring more than $2 \mathrm{~cm}$ in diameter. Mean age of presentation of GST is 60 years with increased prevalence in older age group. There is also an equal male to female predilection. ${ }^{13}$ The commonest sites for GST to occur are thigh and perianal region. ${ }^{1}$ So far 18 cases of GST have been reported; out of which thigh was the site in $3 / 18$ cases and nose was the commonest location of the lesion $(4 / 18) \cdot{ }^{14}$ Other sites were natal cleft, buttock, scrotum, abdomen, shoulder, scalp, perianal, forearm, groin and mammary gland. ${ }^{14}$ The size ranged from 2 to $17 \mathrm{~cm}$ and age ranged from 3 to 71 years. ${ }^{14}$ Most of the cases were treated with excision and showed rare recurrence.

On microscopy, GST is a dermal lesion with no connection to the epidermis. The epidermis is unremarkable. Several horn cysts are present in the lesion which is critical for diagnosis. The horn cysts show abrupt keratinization (trichilemmal keratinization) unlike that seen in squamous cell carcinoma. The basophilic tumor cells are arranged in lace-like adenoid network or sometimes in solid nests and have peripheral palisading. Papillary-mesenchymal bodies are noted in the trichoepithelioma. This is one of the important features in differentiating TE from the other differential diagnosis. Features of high grade atypia with mitosis is not noted. ${ }^{4}$ Secondary features such as foreign body giant cells, calcification and/or amyloid might also be seen. ${ }^{4}$ 


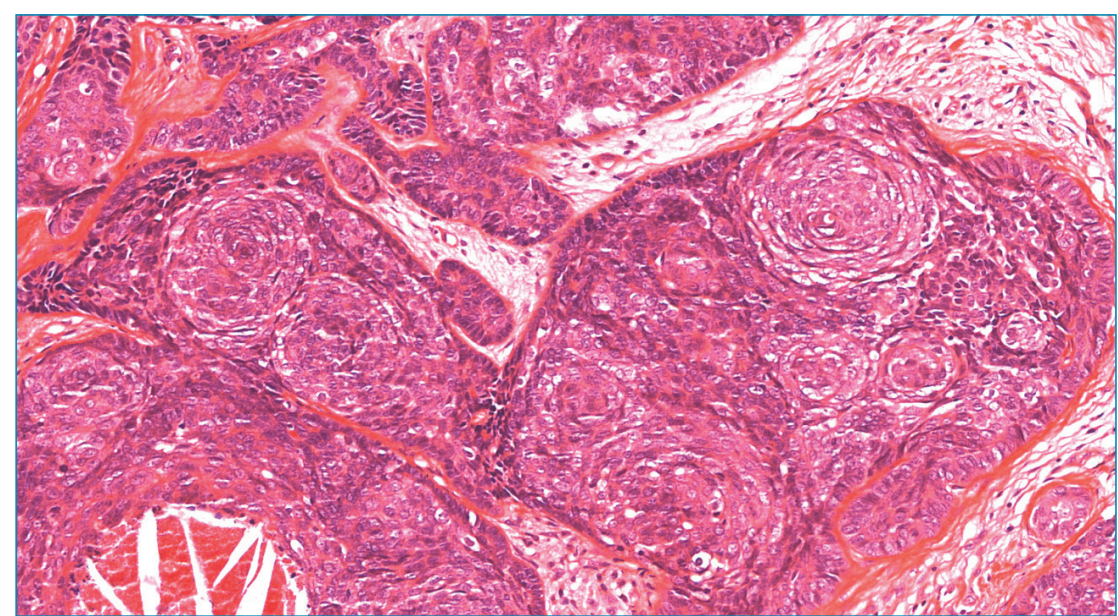

Fig. 2: Basophilic islands of cells with peripheral palisading, horn cysts and several squamous eddies. (HE Stain 10X)

Differential diagnosis of GST include trichoblastoma, keratotic basal cell carcinoma, nevoid basal cell carcinoma and microcystic adnexal carcinoma. Trichoblastoma are less than $1 \mathrm{~cm}$ in size and occur mostly in the scalp. They can be differentiated from the trichoepitheliomas by the absence of horn cysts in trichoblastoma on microscopy. Basal cell carcinomas (BCC) can look very similar to trichoepithelioma, however the former has atypia with brisk mitosis, myxoidstroma and retraction or clefting around the basaloid cells. ${ }^{4}$ BCC lacks the papillary-mesenchymal bodies seen in TE. In few cases, when it's difficult to differentiate between $\mathrm{BCC}$ and TE, immunohistochemistry can be of great use. CD34 is an antigen known to stain the spindle- shaped cells located around the middle portion of normal hair follicles. In TE, cells are positive for CD34, whereas, the spindle-shaped cells surrounding the nests of tumor cells in BCC are are negative for it. ${ }^{15}$ Microcystic adnexal carcinoma, one of the differential diagnosis of GST, is an invasive dermal tumor with cords and nests of keratinocytes having ductal differentiation. ${ }^{4}$

In conclusion, GST is a rare dermal adnexal tumor with hair structures differentiation. The common sites for it being thigh and perianal region. Several adnexal tumors including both benign, as well as malignant adnexal tumor, have to be kept in mind when making a diagnosis of GST.

\section{REFERENCES}

1. Filho GB, Toppa NH, Miranda D et al. Giant solitary trichoepithelioma. Arch Dermatol 1984; 120: 797-8.

2. Tatnall FM, Jones EW. Giant solitary trichoepitheliomas located in the perianal area: a report of three cases. Brit J Dermatol 1986; 115: 91-9.

3. Anderson DE, Howell JB. Epithelioma adenoids cysticum.Genetic update. Brit J Dermatol 1976; 95: 225-32.

4. Lever WF. Histopathology of skin; 4th ed. Philadelphia: JB Lippincott Company; 1967. 557.

5. Mandal AK, Mandal A. Exocrine differentiation of trichoepithelioma and desmoplastic trichoepithelioma: A scanning electron microscopic study. Indian J Pathol Microbiol 1993; 36: 101-3.

6. Rosen LB. A review and proposed new classification of benign acquired neoplasms with hair follicle differentiation. Am J Dermatopathol 1990; 12: 496516.

7. Kim C, KovichOl, Dosik J. Brooke Spiegler syndrome. Dermatol Online J 2007; 13: 10.

8. Michaelsson G, Olsson E, Westermark P. The Rambo syndrome: A familial disorder with vermiculate atrophoderma, milia, hypotrichosis, trichoepitheliomas, basal cell carcinoma and peripheral vasodilation with cyanosis. Acta
Dermatol Venereal 1981; 61: 497-503.

9. Welch JP, Wells RS, Kerr CB. AncellSpieglercylindromas (turban tumours) and BrookeFordyce trichoepitheliomas: evidence for a single genetic entity. J Med Genet 1968; 5: 9-35.

10. Berberian BJ, Sulica VI, Kao GF. Familial multiple eccrinespiradenomas with cylindromatous features associated with epithelioma adenoides cysticum of Brooke. Cutis 1990; 46: 46-50.

11. Burrows NP, Jones RR, Smith NP. The clinicopathological features of familial cylindromas and trichoepitheliomas (BrookeSpiegler syndrome): a report of two families. Clin Exp Dermatol 1992; 17: 332-6.

12. Weedon D. Weedon's skin Pathology. 3rd Ed. Churchill Livingstone Elsevier: China; 2009. 1052

13. Colenje E. Tumours of the skin appendages. In: Burns T, Breathnach S, Cox N, Griffiths C, editors. Rook's Textbook of Dermatology. 8th ed. Vol. 3. West Sussex: Wiley-Blackwell Publishing; 2010.

14. Teli B, Trishuli P B, Santhosh R, Amar D N, Rajpurohit S. Giant solitary trichoepithelioma. South Asia J Cancer 2015; 41-4.

15. Kirchmann TT, Prieto VG, Smoller BR. CD34 staining pattern distinguishes basal cell carcinoma from trichoepithelioma. Arch Dermatol 1994; 130: 589-92. 